\title{
Play, Algorithmic Thinking and Early Childhood Education: Challenges in the Portuguese Context
}

\author{
Maria Figueiredo \\ School of Education and CI\&DEI \\ Polytechnic Institute of Viseu \\ Viseu, Portugal \\ mfigueiredo@esev.ipv.pt
}

Helena Gomes

School of Education,

Polytechnic Institute of Viseu

and CIDMA, University of Aveiro

Viseu, Portugal

hgomes@esev.ipv.pt

Belmiro Rego

School of Education and CI\&DEI,

Polytechnic Institute of Viseu

Viseu, Portugal

brego@,esev.ipv.pt

\author{
Cristina Azevedo Gomes \\ School of Education and CI\&DEI, \\ Polytechnic Institute of Viseu \\ Viseu, Portugal \\ mcagomes@esev.ipv.pt \\ Valter Alves \\ School of Technology and Management \\ and CISeD, \\ Polytechnic Institute of Viseu \\ Viseu, Portugal \\ valter@estgv.ipv.pt
}

\author{
Susana Amante \\ School of Technology and Management \\ and $C I \& D E I$, \\ Polytechnic Institute of Viseu \\ Viseu, Portugal \\ susanamante@estgv.ipv.pt \\ Rui Pedro Duarte \\ School of Technology and Management \\ and $C I S e D$, \\ Polytechnic Institute of Viseu \\ Viseu, Portugal \\ pduarte@estgv.ipv.pt
}

\begin{abstract}
ALGOLITTLE is an EU-funded project, with partners from Portugal, Italy, Turkey, and Slovenia, supporting the integration of algorithmic thinking skills into preschool education for preparing future code literates from an early age. The paper presents the project and frames it in Portuguese Early Childhood Education. First, in terms of curricular areas and pedagogical approach, through a content analysis of the Portuguese Curricular Guidelines for Preschool Education. Second, by analyzing initiatives and projects that are connected to algorithmic thinking in Early Childhood Education in Portugal. Third, by presenting challenges that emerged from a set of discussions with several participants, highlighting the complexity and timeliness of the project.
\end{abstract}

Keywords - early childhood education, algorithmic thinking, pedagogy, curriculum, Portugal.

\section{INTRODUCTION}

Algorithmic thinking is defined as the ability to think in terms of clear, simple and small sequences and repetitive rules to solve a problem or understand a situation [1]-[3]. It can be connected to deep procedural knowledge, which involves understanding procedures, associated with comprehension, flexibility, and critical judgment [4]. Algorithmic thinking is a key ability in Computer Science, but also in daily life. Therefore, it can be developed independently from learning programming and from any technology. In discussing the conceptualization of algorithmic thinking in Early Childhood Education (ECE), it is useful to understand it as connected to computational thinking. But, although they are sometimes used interchangeably, algorithmic thinking and computational thinking are different concepts. The first is commonly included as one of the components of the second [1]-[4] but algorithmic thinking has meaning and applications outside computational thinking [2]. For example, algorithmic thinking has strong connections to Mathematics, outside a computational thinking framework [3].

An algorithm results in a series of steps ordered in a specific sequence to achieve a goal. In ECE, retelling a story in a logical way, ordering objects in a logical pattern, organizing tasks of daily routines, such as washing their hands, or arranging their school bag or lunch box to go to school, are tasks that can involve children in algorithmic thinking [5]. Besides its own relevance, working with algorithmic thinking with ECE children can contribute to their development of computational thinking. Wing [6] described computational thinking as "taking an approach to solving problems, designing systems and understanding human behavior that draws on concepts fundamental to computer science". Computational thinking applies to a large spectrum of disciplines and areas and involves the idea of solving problems, conceptualizing, and thinking at multiple levels of abstraction. Computational thinking, coding and educational robotics are entering European schools as tools for thought, and teachers and curriculum developers are being challenged to foster algorithmic thinking skills starting from ECE [7], [8].

Answering that challenge, ALGOLITTLE is an Erasmus Plus funded project that aims to integrate algorithmic thinking skills into ECE. The aim is to support future ECE teachers to integrate algorithmic thinking in their practices in a meaningful way to raise future digital citizens from an early age. Project partners are İzmir Demokrasi University, Scuola di Robotica, University of Maribor, University of Rijeka, Educloud Eğitim Organizasyon Teknoloji Ticaret Ltd. Şti, and Polytechnic Institute of Viseu (for more information about the project: http://www.algolittle.org).

The intended outputs are a) a curriculum module for teacher education about Algorithmic Thinking in Preschool, and $b$ ) a set of short animations that work as teaching materials for the curriculum. Together, the two outputs will constitute an online course available worldwide about the topic to support initial and continuing teacher education in integrating algorithmic thinking into all subject areas addressed in preschool. The process of designing and evaluating the curriculum and the animations involves all partners in connection with local educational communities. This intends to make the outputs relevant to each country, as well as internationally. 
In this short paper, the context of the project will be presented and challenges regarding the implementation of algorithmic thinking in ECE in Portugal will be described. The challenges resulted from the content analysis of the text of the Portuguese Curricular Guidelines for Preschool Education (CGPSE) that was developed by the team, articulated with contributions from several discussions held with ECE teachers and students from initial ECE teacher education. There is also mention of projects and initiatives about algorithmic thinking in preschool developed in Portugal in recent years.

\section{Preschool and Algorithmic Thinking in Portugal}

ECE in Portugal, when focused on the ages of 3 to 6 years old, is called preschool education. Before the age of three, there is mainly socio-educational provision, whereas preschool education is the first stage of the education system [9]. The Ministry of Education is responsible for ensuring the pedagogical quality of teaching in all preschool education institutions (public and private). Since 1997, there are curricular guidelines for preschool education - the CGPSE [10] - but not a program. These guidelines present three content areas that serve as references for curriculum planning and evaluation [11]: Personal and Social Development, Knowledge of the World and Expression and Communication, including Mathematics, Physical Education, Artistic Education and Oral and Written Language. Although there are different curricular areas, the emphasis is on articulation and connections between them. The teachers' intervention or pedagogy is enacted through the organization of the learning environment and the planning of activities. The learning environment should foster rich play which is highly valued. When organizing the learning environment and planning educational activities, the teacher should create opportunities for learning in all content areas, mostly based on the child's involvement with the environment and other children.

This strong pedagogical autonomy is supported in solid initial teacher education. ECE teachers in Portugal are required to have a Master's Degree, equivalent to all teachers in the educational system. There is also an installed and dynamic system of professional development, with several institutions offering continuing teacher education.

\section{A. Algorithmic thinking in the Portuguese ECE curriculum.}

The CGPSE have several references to technology, particularly in the Knowledge of the World area under Technological World and Use of Technologies [11]. It is valued that children learn about, use and gain a critical understanding of the several technological resources that are part of their life. The pedagogical guidance includes creating opportunities for playing with technology [12] and having access to computers in the school [13], or elsewhere in the community. There is no direct mention of code or coding as the document assumes a more holistic approach to technology as part of the daily and future life of children.

With a larger lens, it is possible to find several opportunities to connect the contents and purposes of learning valued in the CGPSE with algorithmic thinking. For example, in Oral and Written Language, the simplest activities, such as discovering words that start or end with the same sound or letter; identifying the number of syllables in a word by clapping hands, stomping, tapping the desk or speaking like a robot; games suppressing or replacing words in a sentence or following recipes to bake cakes, among so many other activities designed to explore and develop emergent literacy skills, imply algorithmic thinking, as there is data analysis, decomposition, recognition of pattern solution components and decision taking [14]. The same holds true for the Knowledge of the World area that aims "to lay the foundations for structuring scientific thinking" [11] as well as building an attitude of research that must be centered on the ability to observe and on the willingness to experiment with the hypotheses drawn. In a very close formulation to algorithmic thinking, it is expected that children "Ask about reality, define the problem, decide what they want to know and look for a solution" [11]. A recent study investigated curricular areas that were involved in children's activities with computational thinking, both unplugged and with robots [8], and registered moments connected to the areas: Personal and Social Development, Oral and Written Language and Knowledge of the World.

There are several supports for integrating algorithmic thinking with the learning areas. The main challenge is connected to teachers' content knowledge (as well as pedagogical content knowledge and technological pedagogical content knowledge) about algorithmic thinking [15].

\section{B. Algorithmic thinking in Portuguese ECE projects.}

There isn't a strong dynamic of projects that introduce algorithmic thinking in preschool in Portugal. Some exceptions are worth mentioning for their pioneering efforts.

EduScratch has been implemented through a partnership between the Directorate-General for Education of the Portuguese Ministry of Education and Science and its ICT Competence Centers. The School of Education of the Polytechnic Institute of Setúbal presents proposals to work with ScratchJr with preschool children and indicates references to other school levels. EduScratch held training workshops with ECE teachers. There is also a national programming contest, A Criar com Scratch! (Creating with Scratch!), since 2016, that includes a strand for preschool (3to 6-year-old children). However, the impact at practice level has not yet been clearly studied.

Municipalities have been active in promoting coding in their school community. Examples that connect to preschool are Robótica e Programação na Educação Pré-Escolar (Robotics and Programming in Preschool Education), promoted by the Municipality of Santa Maria da Feira, and Pensamento Computacional na Educação Pré-Escolar (Computer Thinking in Preschool Education), presented by the Municipalities of Leiria and Porto de Mós with the Competence Centre Entre Mar e Serra.

Finally, the KML II - Programming technologies and learning laboratory for preschool and elementary school in Portugal should be highlighted as it is focused on the introduction of computational thinking, coding, and robotics activities in both preschool and primary school with a crosscurricular approach [16], [17].

The challenges highlighted by these initiatives refer to distance from classroom work since coding and robotics are mainly offered on a complementary basis. The connection with the curriculum and the integration with the learning areas is adamant. 


\section{Algorithmic thinking in Portuguese teachers' discourse.}

A set of small discussions with different groups was held during 2021, in virtual conference formats. The groups included ECE teachers with more than 20 years of experience, social workers and social-cultural animators working with children from 3 to 10 years old in after-school contexts, initial teacher education students placed in ECE contexts for their practicum, researchers about technology impact on children, Computer Science professors, and ECE teachers working for less than five years (holding a Master's Degree). The data collected throughout the several meetings is still under analysis, but some of the challenges have already been identified in the preliminary results.

The biggest challenge stems from the complexity of the concept of algorithm and of algorithmic thinking itself. Problem-solving and computational thinking, as well as creativity, were connected to algorithmic thinking and this pool of skills and concepts is seen as crucial but also as challenging for children, students, parents, teachers, and future professionals.

There was strong agreement about algorithmic thinking being crosscurricular, not being restricted to one specific learning area - in any level of education - or to one specific context. In ECE classrooms, the outdoor spaces, at home with families, in the after-school and leisure contexts, there are ample opportunities for algorithmic thinking to be made relevant for children. The challenge seems to be to make it relevant for the decision-makers in each context and to articulate the interventions.

In ECE particularly, in terms of activities, there was a strong focus on how to organize the learning environment to promote situations in which algorithmic thinking is suggested to the children. The learning environment dimensions that the participants referred to were the physical environment, including furniture and resources/materials, and the educational routines. It was felt that repetition and a sense of trust were essential to allow children to identify problems that could be approached through algorithmic thinking, hence the importance of the daily routine and of play. The playbased approach was very welcomed, but it sparked debate about the limits of adult intervention in play (free-play vs play-based learning). The challenge here connects to the overall challenge of a quality pedagogy in ECE [18], [19].

Based on existing structures and proposals of a relevant pedagogical approach in ECE [8], [20]-[25], the groups suggested using: whole group or small-group teacher-led activities (cooking, storytelling, physical education, songs and rhymes, dance, science experiments, etc.), play centers (construction area, pretend-play center, table games, etc.), the daily routine activities (washing hands, setting the table for meals, distributing materials, cleaning up, etc.), computer or robot-based activities, outdoor activities (mud kitchens, water and sand, picnics, collections of natural elements, etc.), and a project approach. It was discussed how technology was not needed to introduce algorithmic thinking in ECE but that it was reasonable to connect problem-solving with technological tools and solutions and that the idea of a systematic way to face challenges of different nature should be linked to technology. These connections were seen as important to foster a deep understanding of what technology represents in society but also challenging in terms of the preparation in terms of content knowledge required of the ECE teachers.
Overall, there was agreement that the project is timely and innovative. The challenges about dissemination were mentioned, in relationship to the content knowledge preparation needed for a good pedagogy on algorithmic thinking integration in ECE.

\section{CONCLUSIONS}

Educators can scaffold children's discoveries and ideas by intentionally leading them to develop problem-solving abilities. Problem-solving calls for skills such as analytical ability, creative thinking, initiative, logical reasoning, and persistence. It is important that, from an early age, children can experience meaningful experiences like these. ALGOLITTLE is based on the acknowledgment of the complex and quality work that is developed in ECE. The challenges that emerge regarding the integration of algorithmic thinking in the existing practices are in line with what is recognized as linchpins for quality ECE: strong preparation of the teachers in terms of content knowledge and pedagogy, crosscurricular planning, activities that are diverse in terms of pedagogical approach - enriched play, adult-led proposals, project approach, outdoor settings, and intentional organization of the educational environment. The connection between contexts where the children live their lives was also mentioned and is strongly aligned with the bioecological perspective of the CGPSE [11]. The articulation between an unplugged approach and activities that include technology was also a strong tenet.

The discussion about an unplugged approach is worth mentioning. The purpose of integration with all curricular areas and in all types of pedagogical strategies, namely playbased ones, requires that algorithmic thinking can be thought of in different situations and with different materials, or even no materials. For that purpose, the unplugged approach has proven important. Research also indicates other benefits from that approach [18]-[20].

ALGOLITTLE will debate challenges from the different partner countries. The complicated nature of those explorations and conversations suggests that research on the integration of algorithmic thinking, but also computational thinking, in ECE is taken into account [21]-[23].

\section{ACKNOWLEDGMENTS}

This work was funded by National Funds through the FCT - Foundation for Science and Technology, I.P., within the scope of the project ref. UIDB/05507/2020. Furthermore, we would like to thank the Centre for Studies in Education and Innovation (CI\&DEI) and the Polytechnic of Viseu for their support.

This work was supported by the European Commission through Erasmus+ funding as Algorithmic Thinking Skills through Play-Based Learning for Future's Code Literates, 2020-1-TR01-KA203-092333.

\section{REFERENCES}

[1] A. Csizmadia et al., Computational thinking: A guide for teachers. Computing At School, 2015. [Online]. Available:

https://community.computingatschool.org.uk/resources/2324/single

[2] G. Futschek, 'Algorithmic Thinking: The Key for Understanding Computer Science', in Informatics Education - The Bridge between Using and Understanding Computers, vol. 4226, R. T. Mittermeir, Ed. Berlin, Heidelberg: Springer Berlin Heidelberg, 2006, pp. 159-168. doi: $10.1007 / 1191535515$ 
[3] O. V. Sadykova and G. G. Il'bahtin, 'The Definition of Algorithmic Thinking', presented at the International Session on Factors of Regional Extensive Development (FRED 2019), Irkutsk, Russia, 2020. doi: 10.2991/fred-19.2020.85

[4] E. Lockwood, A. Asay, A. F. DeJarnette, and M. Thomas, 'Algorithmic thinking: An initial characterization of computational thinking in mathematics', in Proceedings of the 38th annual meeting of the North American Chapter of the International Group for the Psychology of Mathematics Education, M. B. Wood, E. E. Turner, M. Civil, and J. A. Eli, Eds. Tucson, AZ: The University of Arizona, 2016, pp. 1588-1595.

[5] M. U. Bers, Coding as a playground: Programming and computational thinking in the early childhood classroom, 2nd ed. New York: Routledge Press, 2021.

[6] J. M. Wing, 'Computational thinking', Commun. ACM, vol. 49, no. 3, pp. 33-35, 2006, doi: 10.1145/1118178.1118215.

[7] B. Strnad, 'Introduction to the World of Algorithmic Thinking', Journal of Electrical Engineering, no. 6, pp. 57-60, 2018.

[8] M. Miranda-Pinto, 'Programación y Robótica en Educación Infantil: Estudio Multicaso en Portugal', Prisma Social, vol. 25, pp. 248-276, 2019.

[9] T. Vasconcelos, Das casas de asilo ao projecto de cidadania - políticas de expansão da educação de infância em Portugal. Porto: Edições ASA, 2005.

[10] Ministério da Educação, Orientações curriculares para a educação pré-escolar. Lisboa: Ministério da Educação, 1997.

[11] Ministério da Educação, Orientações curriculares para a educação pré-escolar [Curricular Guidelines for Preschool Education]. Lisbon: Ministério da Educação, 2016.

[12] M. P. Figueiredo, S. Santos, and B. Rego, 'Playing with technology in Early Childhood Education: creation of a play center', in EduLearn 2021 Proceedings.

[13] M. P. Figueiredo, A. Figueiredo, and B. Rego, 'Peer interaction in mixed age groups: a study in the computer area of an early childhood education center in Portugal', in ICERI2015 Proceedings, Seville, Spain, Nov. 2015, pp. 2548-2554.

[14] M. P. Figueiredo, S. Amante, M. C. Gomes, H. Gomes, B. Rego, and V. Alves, 'Play and Algorithmic Thinking in Early Childhood Education:
An Analysis of the Portuguese Guidelines', presented at the European Conference on Educational Research (ECER), Geneva, 2021.

[15] M. P. Figueiredo et al., 'Algorithmic Thinking in Early Childhood Education: Opportunities and Supports in the Portuguese Context', in EduLearn 2021 Proceedings.

[16] A. F. Monteiro, M. Miranda-Pinto, A. J. Osório, and C. Araújo, 'Coding as literacy: case studies at pre-primary and elementary schools', in INTED2021 Proceedings, 2021. doi: 10.21125/inted.2021.

[17] L. Amante, A. Quintas-Mendes, M. Monteiro, M. Miranda-Pinto, A Osório, and C. L. Araújo, 'Computational thinking, programming and robotics in Basic Education: evaluation of an in-service teacher's training B-Learning experience', in ICERI 2019: 12th International Conference of Education, Research and Innovation: conference proceedings, L. Gómez Chova, D. López Martínez, and I. Candel Torres, Eds. Seville: International Association of Technology Education and Development, 2019, pp. 1069810705.

[18] T. Bell and M. Lodi, 'Constructing Computational Thinking Without Using Computers', Constructivist Foundations, vol. 14, no. 3, pp. 342-351, 2019.

[19] C. P. Brackmann, M. Román-González, G. Robles, J. Moreno-León, A. Casali, and D. Barone, 'Development of Computational Thinking Skills through Unplugged Activities in Primary School', in Proceedings of the 12th Workshop on Primary and Secondary Computing Education, New York, NY, USA, 2017, pp. 65-72. doi: 10.1145/3137065.3137069.

[20] E. A. Lamagna, 'Algorithmic Thinking Unplugged', J. Comput. Sci. Coll., vol. 30, no. 6, pp. 45-52, 2015.

[21] S. Jung and E. Won, 'Systematic Review of Research Trends in Robotics Education for Young Children', Sustainability, vol. 10, no. 4, p. 905, 2018, doi: 10.3390/su10040905

[22] L. Xia and B. Zhong, 'A systematic review on teaching and learning robotics content knowledge in K-12', Computers \& Education, vol. 127, pp. 267-282, 2018, doi: 10.1016/j.compedu.2018.09.007.

[23] M. U. Bers, 'Coding and Computational Thinking in Early Childhood: The Impact of ScratchJr in Europe', European Journal of STEM Education, vol. 3, no. 3, 2018, doi: 10.20897/ejsteme/3868. 